\title{
Antecedents to Adoption of Electronic Payment Systems in Sri Lanka
}

\author{
Dushyantha Kulathunga \\ Department of Information Technology \\ University of Sri Jayewardenepura \\ Nugegoda, Sri Lanka \\ dushyanthak@sjp.ac.lk \\ Kaushalya Wijesinghe Ekanayake \\ IFS R\&D International (Pvt) Ltd. \\ Colombo 06, Sri Lanka \\ kwekanayake@gmail.com \\ DOI: $10.31364 / S C I R J / v 7 . i 9.2019 . P 0919695$ \\ http://dx.doi.org/10.31364/SCIRJ/v7.i9.2019.P0919695
}

\begin{abstract}
Electronic payment systems (EPS) provide an alternative for traditional payment systems. Even though EPS provide a more convenient method for performing transactions, customers have not switched to EPS as expected. Researchers have investigated this issue over the past and they have identified that there are a variety of factors hindering the usage of EPS by customers. Literature review reveals that there are contradictory findings between researchers on this matter and hence it is evident that there is no agreement among the researchers as to which factors really affect the usage of EPS by customers. Therefore, this study aimed at identifying critical factors affecting the customer perception towards the use of EPS. Through a thorough literature review, the researchers could identify five antecedents which have been cited by many researchers as important factors determining the usage of EPS. Amongst them, the present research revealed that "benefits", "trust" and "compatibility" as significant antecedents to the adoption of electronic payment systems in Sri Lanka.
\end{abstract}

Keywords-Electronic payment systems, E-payment systems, Consumer perception, Customer perception, Sri Lanka.

\section{INTRODUCTION}

Electronic payment systems provide a more convenient payment method for customers. Electronic payment systems process the payment electronically, making it much faster and more efficient. Evolution of the Internet and e-commerce transactions have given rise to the need of new payment mechanisms so that customers can accomplish their business transactions efficiently, but in a trustworthy and secure manner (Sumanjeet, 2009).

Today, customers have many options of electronic payment methods. Examples include credit cards, debit cards Internet banking etc. In the Sri Lankan context, technological advancements in payment systems show a growth, but the popularity and usage of Electronic payment systems do not seem to be promising (Kariyawasam et al., 2016).

Researchers have examined the adoption of electronic payment systems in different contexts. Treiblmaier et al. (2008) who studied success factors of Internet payment systems in Austria found that Ease of use, Anonymity, Speed and
Confirming the completion of the transaction significantly influenced attitudes towards online payment. Ozkan et al., (2010) examined the critical factors for consumer adoption of E-Payment Systems, and found that security, trust, perceived advantage, assurance seals, perceived risk and usability are significant. Harris et al. (2011) who investigated factors influencing the perception of E-Payment Systems found that flexibility, functionality, privacy, and security were important factors. However, contrary to above findings, Teoh et al., (2013) found that trust is not significantly associated with consumers' perception of E-Payment Systems.

Thus, the examination of previous research indicates that there are contradictory findings. Therefore, it is evident that there is no agreement among past researchers as to what really determines usage of electronic payment methods from customers' point of view.

Besides, even though there are many studies done abroad which have looked in to the factors affecting the adoption of electronic payment systems, there is a dearth of research in this context in Sri Lanka. Therefore, it is important to study the consumer perception of Electronic payment systems in Sri Lankan context. Consequently, the main objective of this study identify the factors affecting consumer perception towards the usage of electronic payment systems and determining the key antecedents among them.

\section{FACTORS AFFECTING CONSUMERS' PERCEPTION OF ELECTRONIC PAYMENT SYSTEMS}

A comprehensive literature review helped the researchers to identify five factors as possible influential factors of consumer perception on E-payment systems that could be empirically tested in the Sri Lankan context, namely: Benefits, Trust, Selfefficacy, Security, Compatibility. These variables were found to have an impact on consumer perception on E-payment systems by many prior research studies.

The below section includes a review of prior research studies related to the independent variables chosen for this research study. 


\section{A. Benefits}

Bank customers move towards Internet banking because they can enjoy the benefits of less cost and time for online transactions (Pikkarainen et al., 2004; Gerrard and Cunninghamm, 2003).

Shiraj (2015) highlighted that Internet banking saves time and money, and provides convenience and accessibility which attract consumers towards the use of Internet banking. Further, Mols (1998) claims that Internet banking offers more benefits to customers at lower costs. Turban et al. (2000) extended those findings stating that Internet banking is extremely beneficial to customers because of the savings in costs, time and space, quick responses to complaints, and delivery of improved services.

In two studies examining the use of credit cards, Khare et al. (2012) and Gan et al. (2016) found that convenience is a major determinant of credit card use among customers.

In the Sri Lankan context, Jayasiri et al. (2015) found that perceived usefulness is a critical factor affecting the adoption of Internet banking services and Hettiarachchi (2014) found that there is a strong positive relationship between the relative advantage of using Internet banking services and the Internet adoption.

\section{B. Trust}

Trust has a striking influence on a user's willingness to engage in online exchanges of money and personal sensitive information (Wang et al., 2003). Kim et al., (2010) found that consumers' perceived trust has a positive impact on EPS use.

Zhou (2011) argued that mobile service providers need to work on improving initial trust in order to facilitate users' adoption and usage of mobile banking. Kurnia and Benjamin (2007) found that a high level of user confidence and trust in EPayment Systems is a contributing factor for the successful adoption of E-payment systems. Phonthanukitithaworn et al. (2016) identified that perceived trust is a critical factor for consumer adoption of mobile payment services in Thailand.

Abrazhevich (2004) argued that trust of a company is a key factor determining the use of electronic payment systems. Consequently, the users and merchants may opt for an insecure payment system from a trusted company over a secured payment system offered by an untrustworthy company, or a new company which has not been able to establish trustworthiness among customers.

\section{Self-Efficacy}

Davis et al., (1989) and Venkatesh and Davis (1996) suggested that self-efficacy is an antecedent of perceived easeof-use and object usability. Translated to computer and Internet use, computer-related self-efficacy is a natural precursor to using the Internet for commerce.

As O'Cass and Fenech (2003) pointed out, when Internet users accumulate enough personal experience to use computer technology over time, it helps them to build confidence in their ability to use the Internet for commercial purposes. Wang et al., (2003) found computer self-efficacy to have an indirect effect on consumer intentions to use Internet banking systems.

Compeau and Higgins found that self-efficacy has a significant impact on individuals' expectations of outcomes in relation to the use of computers, their emotional reactions (affect and anxiety) to computers, and their actual computer use.
In a study conducted in Sri Lanka, Hettiarachchi (2014) found that there is a relatively significant and positive relationship exist between self-efficacy and usage of Internet banking.

\section{Security}

Sathye (1999) explained that security concerns and a lack of understanding of Internet banking and its benefits are major obstacles to Internet banking adoption in Australia.

Kim et al., (2010) found consumers' perceived security and trust is positively related to consumers' perceived trust and EPS use. Cheng et al. (2006) found that perceived web security to be a significant determinant of a customer's acceptance of online shopping.

In a study on online retail acceptance by Huang and Oppewal (2006), security concerns about credit card details were found to be very significant. Chavosh et al., (2011) found that degree holders were very concerned about the security issues associated with E-Payment services.

Findings of Haque1 et al. (2009) revealed that security of transactions is the most important variable that serves to expand and strengthen the operations of e-Banking.

In a study done in Sri Lanka, Jayasiri et al. (2015) found that perceived security significantly affects the adoption of Internet banking services.

\section{E. Compatibility}

Tan and Teo (2000) found that compatibility, with the respondent's values, experience, and needs, is a significant driver of the adoption of Internet banking. Barbosa and Zilber (2013) revealed that compatibility with current user habits help to boost adoption of mobile payments. Phonthanukitithaworn et al. (2016) concluded that compatibility is a critical factor for consumer adoption of mobile payment services in Thailand

In a study conducted in Sri Lanka, Hettiarachchi (2014) established that there is a relatively moderate positive relationship existed between compatibility of Internet banking with one's own values.

\section{METHODOLOGY}

As illustrated above, the literature review helped the researchers to uncover five key factors affecting the adoption of EPS. Those factors included: Benefits, Trust, Self-Efficacy, Compatibility and Security. Based on those factors and the relationships established by previous researchers, the conceptual model depicted in Figure 1 was developed. The directions of the relationships denoted in Figure 1 are based on the findings of the prior research. 


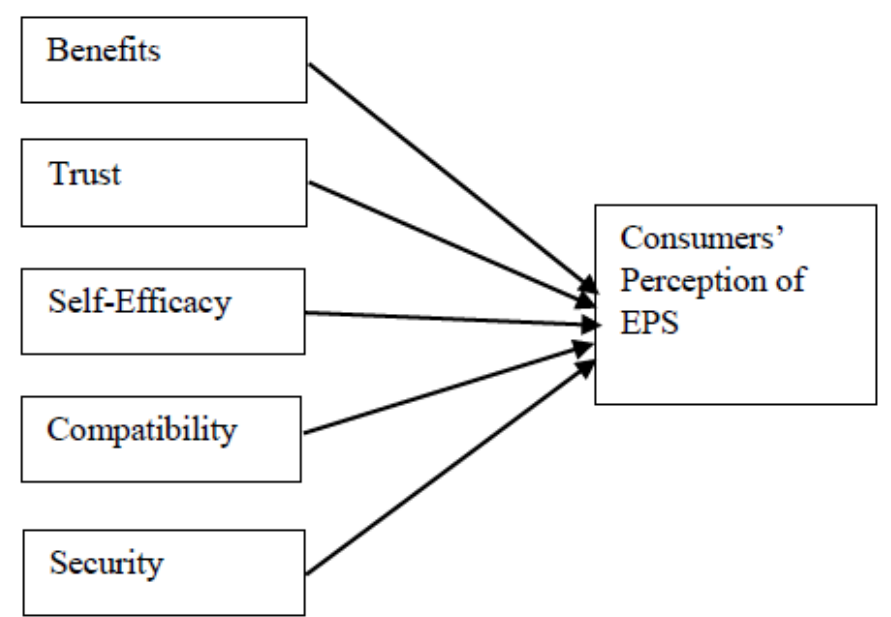

FIGURE 1: CONCEPTUAL FRAMEWORK

\section{A. Hypotheses of the Study}

Based on the above conceptual framework, the researcher developed following five hypotheses to examine the effect of each factor identified there on consumers' perception of EPS.

H1 - There is a positive effect of benefits on consumers' perception of E-Payment Systems.

$\mathrm{H} 2$ - There is a positive effect of trust on consumers' perception of E-Payment Systems.

H3 - There is a positive effect of self-efficacy on consumers' perception of E-Payment Systems.

H4 - There is a positive effect of compatibility on consumers' perception of E-Payment Systems.

H5 - There is a positive effect of security on consumers' perception of E-Payment Systems.

\section{B. population and Sample of the Study}

Sri Lankan consumers who are using E-Payment systems, namely: debit cards, credit cards, Internet banking, telebanking and mobile banking, form the population of the research study.

The unit of analysis of this study was at individual level. Data was collected from a sample of users of the aforesaid EPayment Systems using the convenience sampling method as limited resources were available for research purposes. A sample of 200 who were employed or self-employed in the Colombo district, which is considered as the main commerce and financial hub of the country were selected. Colombo district was purposefully selected since it can be assumed that more people in the Colombo district tend to use Electronic Payment Systems compared to other districts in Sri Lanka due to the development of digital infrastructure there. Similar sampling methods have been used in the study of Wickramasinghe and Gurugamage (2009) and also in the study of Hettiarachchi (2014).

\section{Research Instrument}

A questionnaire was developed to collect primary data from the respondents. Items in the questionnaire were adapted from questionnaires used in previous relevant studies including Compeau and Higgins (1995), Abrazhevich (2001), Wang et al. (2003), Poon (2007), Maditinos et al. (2009), and Teoh et al.
(2013). The questionnaire adopted a 5 point Likert scale, ranging from $1=$ Strongly Disagree to $5=$ Strongly Agree .

\section{Data Collection}

The survey was conducted using the convenience sampling method. 200 respondents were invited through e-mail to participate in the online survey. The survey resulted in 106 responses in total (response rate of 53\%) in which one respondent did not use any of the E-Payment Systems under study. Therefore, 105 responses were used for the analysis of the research study.

\section{E. Data Cleansing}

One outlier was observed from the box plot of the variable, Self-Efficacy, and therefore that particular response was removed from the data set. Hence, the final data set used for further analysis consisted of 104 responses.

\section{DATA ANALYSIS}

\section{A. Descriptive Analysis}

Age distribution of the respondents revealed that the majority of respondents were from the age category of 20-30 $(66 \%)$ while $25 \%$ of the respondents were from the age category of 31-40. The gender distribution of the respondents illustrated that $56 \%$ were females and $44 \%$ were males. The frequencies of the marital status of the respondents illustrated that majority of the respondents were single (57\%). The frequencies of educational levels of the respondents showed that $66 \%$ percent of the respondents were graduates while $22 \%$ were postgraduates.

\section{B. Usage of E-Payment Systems}

The usage of E-Payment Systems of the respondents is depicted in Figure 2. Ninety-three percent $(93 \%)$ of the respondents claimed that they use debit cards which proves that it was the most popular E-Payment system in Sri Lanka. Internet banking was found to be the second most popular EPayment System with the respondents and it accounts for $63 \%$. Credit cards were also very significantly popular among the respondents, where $61 \%$ of the respondents were using credit cards. Mobile phone banking was less popular, and only $27 \%$ of the respondents were using Mobile-phone banking. The usage of Tele-banking was very low among the respondents, where only $5 \%$ of the banking customers used this option.

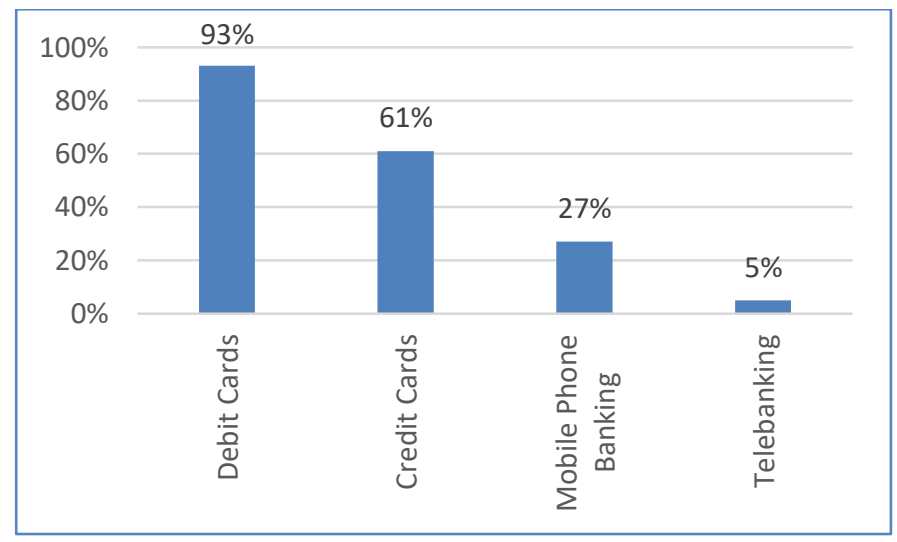

FIGURE 2: EPS USAGE BY THE RESPONDENTS 


\section{Mean Analysis}

Analysis of mean values was performed to identify the most important factors as perceived by the customers. The results are shown in Table 1 . Mean analysis reveal that they range between 3.39 and 4.16. It indicates that all variables have a mean value which is above the average mean value of 3 . Therefore, it is apparent that respondents agree on an above average rate that these factors influence the consumers' perception of EPS usage.

TABLE 1: MEAN ANALYSIS

\begin{tabular}{|l|r|r|}
\hline Variable & \multicolumn{1}{|l|}{ Mean } & $\begin{array}{l}\text { Standard } \\
\text { Deviation }\end{array}$ \\
\hline Benefits & 4.16 & 0.56 \\
\hline Compatibility & 3.95 & 0.62 \\
\hline Security & 3.80 & 0.79 \\
\hline Trust & 3.42 & 0.71 \\
\hline Self-efficacy & 3.39 & 0.71 \\
\hline
\end{tabular}

\section{Validity and Reliability Analysis}

Sampling adequacy was tested using Barlett test of Sphericity and Kaiser-Meyer-Olkin (KMO) test. According to Table 2, Barlett test of Sphericity was significant at at $99 \%$ confidence level and that the Kaiser-Meyer-Olkin (KMO) values for all variables were above 0.5 indicating the sampling adequacy for factor analysis.

\section{TABLE 2: KMO AND BARTLETT'S TEST OF SPHERICITY}

\begin{tabular}{|c|c|c|c|c|}
\hline Variable & KMO & $\begin{array}{c}\text { Bartlett's } \\
\text { Test of } \\
\text { Sphericity }\end{array}$ & $\begin{array}{c}\text { Eigen } \\
\text { Values }\end{array}$ & $\begin{array}{c}\% \text { of } \\
\text { Variance } \\
\text { Explained }\end{array}$ \\
\hline Compatibility & \multirow{5}{*}{0.722} & \multirow{6}{*}{0.000} & 8.206 & 22.242 \\
\hline Trust & & & 3.256 & 11.504 \\
\hline Benefits & & & 2.46 & 9.926 \\
\hline Self-Efficacy & & & 1.607 & 9.436 \\
\hline Security & & & 1.493 & 7.057 \\
\hline $\begin{array}{l}\text { Consumer } \\
\text { Perception }\end{array}$ & 0.852 & & 1.115 & 7.008 \\
\hline
\end{tabular}

Factor analysis yielded five independent factors related to the five factors identified in the conceptual framework. Except for two items, all factor loadings were above 0.5 indicating high internal consistency (Hair et al., 2014). One item related to "Benefits" had a loading of 0.438 and one item related "Consumer Perception of EPS" had a factor loading of 0.491 . Due to the explorative nature of this study, the researchers decided to proceed with those two items.

Cronbach's alpha is a measure of reliability that ranges from 0 to 1 , with values of 0.6 to 0.7 deemed as the lower limit of acceptability (Hair et al., 2014). Therefore, Cronbach's $\alpha$ scores were checked for each variable to ensure reliability. The variables resulted in Cronbach's $\alpha$ scores ranging from 0.747 (Security) to 0.889 (Compatibility) as depicted in Table 3. Therefore, Cronbach's $\alpha$ values for all the variables were higher than 0.7 , implying that all the constructs demonstrate high internal consistencies (Hair et al., 2014).

TABLE 3: RELIABILITY ANALYSIS

\begin{tabular}{|l|c|c|}
\hline Measure & $\begin{array}{c}\text { No. of } \\
\text { Items }\end{array}$ & $\begin{array}{c}\text { Cronbach's } \\
\boldsymbol{\alpha}\end{array}$ \\
\hline Benefits & 6 & 0.784 \\
\hline Trust & 4 & 0.808 \\
\hline Self-Efficacy & 4 & 0.751 \\
\hline Compatibility & 4 & 0.889 \\
\hline Security & 4 & 0.747 \\
\hline Consumer Perception of EPS & 5 & 0.843 \\
\hline
\end{tabular}

Further, the researchers did not notice any multicollinearity issue since correlation coefficients among the independent variables ranged between 0.061 and 0.568 , which is below the cut-off point of 0.90 (Hair et al., 2014).

\section{E. Correlation Analysis}

Table 4 shows the correlation between each of the five independent variables and Consumer Perception of EPS (dependent variable). According to the correlation coefficients there, it is apparent that the independent variables Benefits, Trust, Compatibility, and Security have positive and significant relationships $(p<0.05)$ with Consumers' Perception of EPS. However, the correlation coefficient of the variable Selfefficacy is not significant ( $p>0.05$ ). Hence, it can be stated that there is no significant relationship existing between Selfefficacy and Consumers' Perception of EPS.

TABLE 4: CORRELATION ANALYSIS

\begin{tabular}{|l|c|c|c|l|l|}
\hline & Benefits & Trust & $\begin{array}{l}\text { Compa- } \\
\text { tibility }\end{array}$ & $\begin{array}{l}\text { Secu- } \\
\text { rity }\end{array}$ & $\begin{array}{l}\text { Self- } \\
\text { Effi- } \\
\text { cacy }\end{array}$ \\
\hline Trust & $0.345^{* *}$ & & & & \\
\hline $\begin{array}{l}\text { Compati- } \\
\text { bility }\end{array}$ & $0.568^{* *}$ & $0.301^{* *}$ & & & \\
\hline Security & $0.286^{* *}$ & 0.139 & 0.170 & & \\
\hline $\begin{array}{l}\text { Self- } \\
\text { Efficacy }\end{array}$ & 0.170 & $0.252^{* *}$ & 0.061 & $0.307^{* *}$ & \\
\hline $\begin{array}{l}\text { Consumer } \\
\text { Perception }\end{array}$ & $0.631^{* *}$ & $0.419^{* *}$ & $0.802^{* *}$ & $0.238^{*}$ & 0.173 \\
\hline
\end{tabular}

$* *$ Correlation is significant at the 0.01 level (2-tailed).

* Correlation is significant at the 0.05 level (2-tailed).

\section{F. Multiple Regression Analysis}

Multiple regression can be useful in several ways. It can be used to determine strength of the effect or impact of independent variables on the dependent variable. It is also useful in predicting the changes of the dependent variable when independent variables are changed. Consequently, the researcher decided to use multiple regression analysis to test the hypotheses of the study as it was identified as the most suitable analysis, given the nature to the hypotheses.

Model Summary of the multiple regression analysis is shown in Table 5. According to this table, the five independent variables used in the research study explains $69.8 \%$ (i.e. Adjusted R Square value of Table 4) of the variation of the 
dependent variable (Consumers' Perception of EPS). Consequently, it can be inferred that the research model used in this study is quite convincing and the model satisfactorily explains the relationships existing between the independent variables Benefits, Trust, Compatibility, Security, and Selfefficacy and the dependent variable Consumers' Perception of EPS.

TABLE5: MODEL SUMMARY ${ }^{b}$

\begin{tabular}{|l|c|c|c|c|}
\hline Model & $\mathrm{R}$ & $\begin{array}{c}\mathrm{R} \\
\text { Square }\end{array}$ & $\begin{array}{c}\text { Adjusted R } \\
\text { Square }\end{array}$ & $\begin{array}{c}\text { Std. Error of the } \\
\text { Estimate }\end{array}$ \\
\hline 1 & $.844^{\mathrm{a}}$ & .713 & .698 & .34745 \\
\hline
\end{tabular}

a. Predictors: (Constant), Self-Efficacy, Compatibility, Security, Trust, Benefits

b. Dependent Variable: Consumer Perception of EPS

Table 6 shows the multiple regression coefficients and whether they are significant or not. According to this table, regression coefficients related the variables Benefits, Trust and Compatibility are significant $(\mathrm{p}<0.05)$. Consequently, it can be concluded that the impact of these three variables on Consumer Perception of EPS is significant. However, it is visible from Table 5 that the coefficients related to the variables Security and Self-efficacy are not significant. Hence, the results reveal that the impact of those two variables on Consumer Perception of EPS is not significant.

TABLE 6: REGRESSION COEFFICIENTS

\begin{tabular}{|l|c|c|c|}
\hline & $\begin{array}{c}\text { Unstandardized } \\
\text { Coefficients }\end{array}$ & $\begin{array}{c}\text { Standardized } \\
\text { Coefficients }\end{array}$ & Sig. \\
\hline & B & Beta & \\
\hline (Constant) & -0.255 & & \\
\hline Benefits & 0.230 & 0.202 & $\mathbf{0 . 0 0 4}$ \\
\hline Trust & 0.124 & 0.140 & $\mathbf{0 . 0 2 1}$ \\
\hline Compatibility & 0.646 & 0.635 & $\mathbf{0 . 0 0 0}$ \\
\hline Security & 0.030 & 0.037 & 0.532 \\
\hline Self-Efficacy & 0.047 & 0.053 & 0.366 \\
\hline
\end{tabular}

\section{G. Validation of Hypotheses}

The five hypotheses proposed for this study was validated from the multiple regression results. The summary of the findings is given in Table 7. According to the results, hypotheses $\mathrm{H} 1, \mathrm{H} 2$ and $\mathrm{H} 4$ are accepted while hypotheses $\mathrm{H} 3$ and $\mathrm{H} 5$ are rejected.

TABLE 7: HYPOTHESES TESTING

\begin{tabular}{|l|c|c|l|}
\hline Hypothesis & $\beta$ & $\mathrm{p}$ & Result \\
\hline H1 & 0.202 & $\mathbf{0 . 0 0 4}$ & Accept \\
\hline H2 & 0.140 & $\mathbf{0 . 0 2 1}$ & Accept \\
\hline H3 & 0.053 & 0.366 & Reject \\
\hline H4 & 0.635 & $\mathbf{0 . 0 0 0}$ & Accept \\
\hline H5 & 0.037 & 0.532 & Reject \\
\hline
\end{tabular}

\section{DISCUSSION}

\section{A. Effects of Benefits on Consumers' Perception of EPS}

As per Davis, (1989), Benefits refer to the degree to which a person believes that using a particular system would enhance his or her job performance. Benefits reported the highest overall mean and the lowest standard deviation. In addition, it has the second highest beta value and the second highest correlation coefficient. The indicators of the benefits variable including time savings, accuracy, speed, convenience and flexibility scored mean values of more than 4 except for cost savings. This means that the consumers are more concerned about the benefits provided by the E-Payment Systems. Therefore, benefits variable was found to be a significant determinant of consumers' perception of E-Payment Systems. Specifically, there was a positive relationship between benefits and consumers' perception of E-Payment Systems. These findings are consistent with the prior research studies of Davis (1989); Chakravorti, (2003); Sumanjeet, (2009); Teoh et al., (2013); Tella et al., (2015).

\section{B. Effect of Trust on Consumers' Perception EPS}

Trust is defined as a function of the degree of risk involved in financial transactions, and the outcome of trust is reduced perceived risk, leading to positive intentions toward E-payment adoption (Yousafzai et al., 2003). Trust is found to be a significant determinant of consumers' perception of E-Payment Systems. The correlation and regression results suggested that consumers' perception of E-Payment Systems is substantially driven by trust factor. Further, it is evident that there is a positive relationship between trust and consumers' perception of E-Payment Systems. These findings are consistent with prior research done by Abrazhevich, (2001), Kurnia and Benjamin, (2007), Black (2005); Abrazhevich (2004); Özkan et al., (2010) and Zhou (2011).

\section{Effect of Security on Consumers' Perception of EPS}

Security may be defined as protecting the details of transactions and customers from internal and external fraud or criminal usage (Özkan et al., 2010). As per descriptive statistics, security was found to be an important factor with a mean value close to four but reports the highest standard deviation. However, the regression results explained that security is not a significant driver of consumers' perception of E-Payment Systems even though correlation suggests otherwise. This means that even if there was a relationship between security and consumers' perception of E-Payment Systems, the relationship was not very substantial. This was also supported by the low correlation coefficient. Security breaches and anonymity as indicators of the security variable have a mean of more than four where technical security protections and security statements have low mean values. The overall research results suggested that security should not be overlooked even though the regression results do not present security as a significant determinant of consumers' perception of E-Payment Systems. The findings of Teoh et al., (2013) also identified security as not significant in determining consumers' perception of E-Payment Systems and yet the researchers do note that security should not be discounted.

\section{Effect of Self-efficacy on Consumer Perception of EPS}

Bandura, (1986) defined Self-efficacy as the judgment of one's ability to use E-Payment Systems derived at by the experience of one's personal mastery. Self-efficacy was reported to have the lowest overall mean value along with 
lowest beta value in the regression analysis. Both the correlation analysis and multiple regression results suggested that self-efficacy was not significantly associated with consumers' perception of E-Payment Systems.

The reason for this could be that Sri Lankan consumers are highly aware about E-Payment Systems as they have been using them for a considerable period of time. Debit cards were first introduced to Sri Lanka in 1997 while credit cards were issued in 1989. Internet banking was introduced in Sri Lanka in 1999 (Jayamaha, 2008; Central Bank of Sri Lanka, 2017). Therefore, the consumers have experience and knowledge of E-Payment Systems such that they may not require peer recommendations, help facilities, visual experience to build confidence in themselves or when deciding to use E-Payment Systems, rather they rely on the information and awareness programs of banks and E-Payment System operators. This finding is consistent with the findings of Maditinos et al. (2009).

\section{E. Effect of Compatibility on Consumer Perception of EPS}

Compatibility is the degree to which the innovation fits with the potential adopter's existing values, previous experience and current needs (Shih and Fang, 2004). Epayment systems allow contemporary consumers to perform their transactions smoothly as they fit well with the modernday needs. The correlation and regression results revealed that compatibility is a significant influential factor to consumers' perception of E-Payment Systems. The mean scores also agreed with those results with a high mean score close to four. Compatibility had the highest correlation coefficient and the highest beta value suggesting a very substantial influence on consumers' perception of E-Payment Systems. This means that Sri Lankan consumers are highly sensitive to the fact that EPayment Systems fit well with their existing values, previous experience and current needs. Therefore, the consumers seem to be in agreement with the fact that compatibility is an essential characteristic of E-Payment Systems. This supported the Innovation Diffusion Theory of Rogers, (2003) and is consistent with the findings of Tan and Teo (2000); Maditinos et al., (2009); Phonthanukitithaworn et al., (2016) and Hettiarachchi, (2014).

\section{CONCLUSION}

The research study examined the factors influencing the consumers' perception of E-Payment Systems. The multiple regression results indicated that benefits, trust and compatibility have a significant positive impact on consumers' perception of E-Payment Systems and hence, they can be considered as the key antecedents influencing the perception of consumers in using different electronic payment systems. Moreover, security and self-efficacy also showed a positive relationship with consumers' perception of E-Payment Systems even though they were found to be not significant.

\section{A. Theoretical Implications}

In reviewing literature, it was observed that there is a lack of research on consumers' perception of Electronic payment systems. Prior researchers have focused on consumer attitudes and usage of Electronic payment systems and in certain studies, on individual types of Electronic payment systems, but few studies have investigated consumers' perception of Electronic payment systems and the factors that determine it. In the local context, research studies on consumers' perception of Electronic payment systems was observed to be minimal. Therefore, this research study contributes to fill the existing research gap prevailing in this knowledge area.

\section{B. Practical Implications}

There is high a potential for growth of E-Payment Systems in Sri Lanka as more and more users opt for such methods. Since this study has revealed that "Benefits", "Trust", and "Compatibility" are significant factors influencing the use of EPS, the Sri Lankan organizations in the financial and banking sector can focus on those factors more to increase the use of EPS by their customers. Those organizations may improve their performance by moving more customers to EPS as these options are low cost modes for the organizations.

\section{Limitations of the Study}

This research study is limited to five types of E-Payment Systems available in Sri Lanka namely: Debit cards, Credit cards, Internet banking, Mobile phone banking and Telebanking. Further, the findings are based on a sample of 104 users in Colombo district. Finally, the impact of demographic factors such as age, gender, income, and education level on the research findings was not taken into account in this study.

\section{Areas for Future Research}

The research study may be repeated using a much larger sample covering an extended geographical area, and using a stratified sampling method such that the results could be more generalizable. Moreover, the research study could be extended to include demographic factors such as age, income level, gender and educational level as mediating variables. Moreover, a research study to identify the gap between consumer expectations and consumer experience of E-Payment Systems could be undertaken as a gap analysis to identify possible areas of improvement for E-Payment Systems. Such a study would certainly be a fruitful study.

\section{REFERENCES}

Abrazhevich, D. (2001), "Electronic payment systems: issues of user acceptance", in Stanford-Smith, B. and Chiozza, E. (Eds), E-Work and E-Commerce, IOS Press, Amsterdam, pp. 354-360.

Abrazhevich, D. (2004) Electronic payment systems: A usercentered perspective and interaction design, $\mathrm{PhD}$ Thesis, Technical University of Eindhoven, ISBN 90-386-1948-0, DOI: 10.6100/IR575913.

Bandura, A. 1986. Social Foundations of Thought and Action: A Social Cognitive Theory, Prentice-Hall, Englewood Cliffs, NJ.

Black, G.S. 2005. Predictors of consumer trust: likelihood to pay online. Marketing Intelligence \& Planning. 23(7), pp.648-658.

Central Bank of Sri Lanka. 2017. Payments Bulletin-First Quarter 2017, pp. 14-32

Chakravorti, S. 2003. Theory of Credit Card Networks: A Survey of the Literature. Review of Network Economics, Vol. 2, No. 2, pp. 50-68.

Chavosh, A., Halimi, A.B. and Espahbodi, S. 2011. Comparing the Satisfaction with the Banks E-Payment 
Services between Degree holder and Non-degree holder Customers in Penang- Malaysia. International Journal of eEducation, e-Business, e-Management and e-Learning, 1(2), pp. 103-109.

Cheng, T., Lama, D. and Yeung, A. 2006. Adoption of Internet banking: An Empirical Study in Hong Kong. Decision Support Systems. 42(3), pp. 1558-1572

Compeau, D.R. and Higgins, C.A. 1995. Computer SelfEfficacy: Development of a Measure and Initial Test. MIS Quarterly. pp.189-211.

Davis, F.D., 1989. Perceived usefulness, perceived ease of use, and user acceptance of Information Technology. MIS Quarterly. pp.319-340.

Gerrard, P., Cunningham, J.B. 2003. The Diffusion of Internet banking among Singapore consumers. International journal of bank marketing. 21(1), pp.16-28.

Hair, J.F., Black, W.C., Black, W.C, Babin, B.J and Anderson R.E. 2014. Multivariate Data Analysis. 7th ed. Pearson Education Limited.

Harris, H., Guru, B.K. and Avvari, M.V., 2011. Evidence of Firms' Perceptions toward Electronic Payment Systems (EPS) in Malaysia. International Journal of Business and Information, 6(2). pp.226-245.

Hettiarachchi, H.A.H. 2014. Factors Affecting to Customer Adoption of Internet banking. Kelaniya Journal of Management. 2(2), pp.68-87.

Huang, Y. and Oppewal, H., 2006. Why Consumers Hesitate to Shop Online: An Experimental Choice Analysis of Grocery Shopping and the Role of Delivery fees. International Journal of Retail \& Distribution Management. 34(4/5), pp.334-353.

Jayamaha, R., 2008. Impact of IT in the Banking Sector. BIS Review, 13, pp.1-8.

Jayasiri, N.K., Gunawardana, K.D. and Dharmadasa, P., 2015. Adoption of Internet Banking in Sri Lanka: An Extension to Technology Acceptance Model. 2(1), pp.179-189.

Kariyawasam N.J and Jayasiri N.K, 2016. Awareness and Usage of Internet Banking Facilities in Sri Lanka. International Journal of Scientific Research and Innovative Technology. 3(6), pp.173-190.

Khare, A., Khare, A. and Singh, S., 2012. Factors Affecting Credit card use in India. Asia Pacific Journal of Marketing and Logistics. 24(2), pp.236-256.

Kim, C., Mirusmonov, M., \& Lee, I. 2010. An Empirical Examination of Factors Influencing the Intention to Use Mobile payment. Computers in Human Behaviour, 26(3), pp.310-322.

Kurnia, S. and Benjamin, L. (2007). Exploring the reasons for a failure of electronic payment systems a case study of an Australian company. Journal of Research and Practice in Information Technology, 39 (4), 34-67.

Maditinos, D., Tsairidis, C. and Grigoriadis, C., 2009, June. Internet banking User Acceptance: Evidence from Greece and Bulgaria. In 5th HSSS Conference, Democritus University of Thrace, Xanthi, Greece, pp. 24-27.

Mols, N.P., 1998. The Behavioral Consequences of PC banking. International Journal of Bank Marketing, 16(5), pp.195-201
O'Cass, A., \& Fenech, T. 2003. Web Retailing Adoption: Exploring the Future of Internet user's web Retailing Behaviour. Journal of Retailing and Consumer Services, 10(2), pp.81-94.

Özkan, S., Bindusara, G. and Hackney, R., 2010. Facilitating the Adoption of E-Payment systems: Theoretical Constructs and Empirical Analysis. Journal of Enterprise Information Management. 23(3), pp.305-325.

Phonthanukitithaworn, C., Sellitto, C. and Fong, M.W. 2016. An Investigation of Mobile payment (m-payment) services in Thailand. Asia-Pacific Journal of Business Administration. 8(1), pp.37-54.

Pikkarainen, T., Pikkarainen, K., Karjaluoto, H. and Pahnila, S., 2004. Consumer Acceptance of Online banking: An Extension of the Technology Acceptance Model. Internet Research, 14(3), pp.224-235.

Poon, W.C., 2007. Users' Adoption of E-banking Services: The Malaysian Perspective. Journal of Business \& Industrial Marketing. 23(1), pp.59-69.

Rogers, E.M. 2003. Diffusion of Innovations. 5th ed. Free Press. New York, NY.

Sathye, M., 1999. Adoption of Internet banking by Australian Consumers: An Empirical Investigation. International Journal of bank marketing, 17(7), pp.324-334.

Shih, Y.Y. and Fang, K., 2004. The Use of a Decomposed Theory of Planned Behavior to Study Internet banking in Taiwan. Internet research. 14(3), pp.213-223.

Shiraj M.M, (2015), "Factors Influencing the Adoption of Internet Banking: (Special Reference to the South Eastern Region, Sri Lanka)" Faculty of Islamic Studies \& Arabic Language, South Eastern University of Sri Lanka, Second International Symposium (2015), pp.183-190

Sumanjeet, S., 2009. Emergence of Payment Systems in the Age of Electronic Commerce: The State of Art. Asia Pacific Journal of Finance and Banking Research. 3(3), pp.20-40

Tan, M., and Teo, T.S.H. 2000. Factors Influencing the Adoption of Internet-banking. Journal of the Association for Information Systems. 1(5), pp.1-42.

Tella, A. and Abdulmumin, I., 2015. Predictors of Users' Satisfaction with E-payment System: A Case Study of Staff at the University of Ilorin, Nigeria. Organizacija, 48(4), pp.272-286.

Teoh, M.Y, W., Choy Chong, S., Lin, B. and Wei Chua, J., 2013. Factors Affecting Consumers' Perception of Electronic payment: An Empirical Analysis. Internet Research, 23(4), pp.465-485.

Treiblmaier, H., Pinterits, A. and Floh, A., 2008. Success Factors of Internet Payment Systems. International Journal of Electronic Business. 6(4), pp.369-385.

Venkatesh, V. and Davis, F.D. 1996. A Model of the Antecedents of Perceived Ease of Use: Development and Test. Decision Science. 27(3), pp.451-481.

Wang, Y.S., Wang, Y.M., Lin H.H. and Tang, T.I., 2003. Determinants of User Acceptance of Internet banking: An Empirical Study. International Journal of Service Industry Management. 14(5), pp.501-519. 
Wickramasinghe, V. and Gurugamage, A., 2009. Consumer Credit Card Ownership and Usage Practices: Empirical Evidence from Sri Lanka. International Journal of Consumer Studies, 33(4), pp.436-447.

Zhou, T. (2011) "Examining the critical success factors of mobile website adoption", Online Information Review, Vol. 35 Issue: 4, pp.636-652
Zhou, T., 2011. An Empirical Examination of Initial Trust in Mobile-banking. Internet Research. 21(5), pp.527-540. 